\title{
Utilization of Internationally Published Textbooks within Curriculum 2013: Practice and Tension
}

\author{
Nurdiana Mahdalena Sinurat*, Bachrudin Musthafa, Yanty Wirza \\ English Language Department, Universitas Pendidikan Indonesia \\ *Corresponding author. Email: sinuratnurdiana@upi.edu
}

\begin{abstract}
The utilization of internationally published textbooks may pose problems in English language teaching in Indonesia context within Curriculum 2013. It is problematic because both have different goals in leading the process of teaching. Taking places at two private schools in Bandung, using multiple case studies, the research aims to elaborate the tension happen in the practice of utilizing the internationally published textbook within Curriculum 2013. The findings showed it in different nuance from both schools. SHS Bumi utilized the internationally published textbook by attempting to do adjustment between the learning materials from the textbook to the basic competencies (KI-3) in EFL syllabus; meanwhile SHS Pertiwi did that by completely follow the guideline given in the internationally published textbook. This differentiation appears as the result of different beliefs possessed by the teachers from both schools. The more positive the belief of the internationally published textbooks and Curriculum 2013 possessed by the teachers, the less tension that they experienced in utilizing the internationally published textbook within the framework of Curriculum 2013. The better understanding the teachers have about the essence of basic competencies and goals of Curriculum 2013, the better process of utilizing the internationally published textbook that the teachers can do.
\end{abstract}

Keywords: International published textbook, Curriculum 2013, classroom practices, educational policy

\section{INTRODUCTION}

In teaching English as a Foreign Language, textbooks are the essential components that determine where the teaching goes. They are essential because they tell the teachers what to teach and in what order (Davies \& Pearse, 2000). There are two kinds of English textbooks that can be used as the source of learning in Indonesia. They are internationally published textbooks and locally published textbooks. Internationally published textbooks are the textbooks that are published by foreign publisher such as Cambridge University Press, Oxford University Press and Pearson Education (Taki, 2008). Locally published textbooks are the textbooks that are written and produced by Indonesian people.

As a part of Expanding Circle countries (Bolton, 2012), the use of internationally published textbooks in Indonesia is higher than the use of locally published textbooks (Zacharias, 2005). But that is not the problem.
The problem is about how the teachers adjust the materials from the internationally published textbooks into the framework of Curriculum 2013.

Curriculum 2013 is the national curriculum that is used as the foundation of learning in Indonesia. It contains of four core competencies: spiritual competence, social competence, cognitive competence, and psychomotor competence. It has a goal to prepare Indonesian people to be productive, creative, innovative, and affective with future competences needed such as communication skill, critical thinking skill, making decision skill, responsibility, understanding, tolerance, and socialization skill (Kemdikbud, 2014).

In terms of linguistic theory, Curriculum 2013 employs sociolinguistic embracing systemic functional linguistic (see Eggins, 2004; Halliday, 1987) and social semiotics (see Halliday, 1978) which emphasize that language is a tool for communication and meaning making in social context. Therefore, this curriculum 
aims to provide (learner) outcomes with communicative skill (Yulia, 2013).

As a national curriculum, Curriculum 2013 has determined the core and basic competencies that are needed to be achieved. These competencies are described in the EFL syllabus. In that syllabus, English competencies for Senior High School are divided into three types of discourse: interpersonal, transactional, and functional. These competencies are required for oral and written communication acceptable in personal, social, cultural, and academic context. In other words, the classroom activities should involve the integration of four language skills: listening, speaking, reading, and writing.

As mentioned earlier, the problem that is intended to be researched in this study is about how the teachers utilize the internationally published textbooks within the framework of Curriculum 2013. The utilization is seen from how the teachers did the adjustment between the materials from the internationally published textbooks with the core and basic competencies of English (subject) in Curriculum 2013.

Regarding the choice to use the internationally published textbooks, teachers are helped to bridging generations and improving communication within the family and the extended family, building the international links, experiencing two cultures, being able to compare values and worldviews, and becoming biliterate (Marcos, 1998). However, they are bound to face the dualism in following the syllabus. It happens because the textbooks used have automatically become 'the syllabus' (Murphy, 2018) made by the author.

This is dilemmatic as they need to choose which syllabus should be the anchor of their teaching. But one essential role that is often to be neglected by the teachers due to the implementation of policy in classroom practices is that they are the key players in implementing macro policy decision in practice at the micro level (Kirkgoz, 2009 p. 678).

As the key players, teachers have power to organize the learning in the classroom including the choice and the use of the textbooks. In relation to the textbook's choice and use, teachers' beliefs play a role as instrumental in defining task and selecting cognitive tools with which to interpret, plan, and make decisions regarding such task (Pajares, 1992 in Abbit, 2011).

Furthermore, Ledger, Vidovich, and Donoghue (2014) explain how beliefs influence the process of adopting curriculum and using the internationally published textbooks because it is believed to have a connection with the teachers' professional responsibility. Improving professional responsibility should come first before a school adopts an international curriculum.
Previous study (Vijayshima, 2013) shows there is a tendency to direct the students' use of the textbooks where the teachers preferred to control the flow of the materials based on the textbook's content and not based on the mandated curriculum. Swan and Smith (2001) found that the learners may face cross-cultural differences, especially by using the internationally published textbooks which contain western culture that has fundamental differences from eastern culture (Sheedy, 2011). Therefore, the teachers should find a culturally appropriate context for any linguistic item they teach (Lindsay, 2000) without being fear of the transformation of the learners' lives in the context of losing their own cultural values and shifted into western lifestyles as what is argued by Chakravarti (2008).

Peterson and Coltrane (2003) emphasize the teachers to consider the contextualization of language by appreciating more on the right context for using language properly rather than sticking to the grammar and rules of a language. Therefore, it is important to investigate the extent to which principles and recommendations in official curriculum documents are realized at the level of classroom practices (Nunan, 2003), where textbooks often serve as crucial resources (Tomlinson, 2012).

\section{METHOD}

\subsection{Research Design}

This study employed a multiple case study in a qualitative approach to achieve the research objectives, that are, to elaborate the utilization process in (1) selecting the learning materials, (2) setting the goals of learning, (3) teaching the materials from the internationally published textbooks within the framework of Curriculum 2013, and (4) to elaborate the teachers' and staff managements' beliefs of the internationally published textbooks and Curriculum 2013. Multiple sources of data as discussed by Yin (2003) and Creswell (2012) such as document analysis, interview and observations were employed to gather the data.

\subsection{Data Source}

The data sources of this study were the document analysis of EFL Syllabus of Curriculum 2013 and the content of the internationally published textbook, interview and the observation field note. The document analysis was focused on the core and basic competencies listed in the syllabus, the lesson plan, and the learning materials from the internationally published textbook, limited from chapter 1 to chapter 4 from each textbook (Aim High 4 and Choices).

The interview was done to the EFL teachers grade $\mathrm{X}$ from two schools (all is written in pseudonyms): SHS Bumi and SHS Pertiwi. The EFL teacher from SHS 
Bumi is Ms. Ruth and one curriculum staff, Ms. Jean. The EFL teachers from SHS Pertiwi are Ms. Dinda, Ms. Lena and Mr. Peter who is also the coordinator of EFL teachers there. The other participant is the superintendent of Bandung Education Office, Mrs. Marini.

Both schools were chosen because they utilize the internationally published textbooks in the EFL learning and acknowledge Curriculum 2013 in the process of learning. The superintendent was involved to gain indepth data about how the EFL teachers should response towards the use of internationally published textbook within Curriculum 2013.

\subsection{Data Analysis}

The data collection process was started with asking permission to the school principal of both schools and the superintendent of Bandung Education Office. The interview was done to all participants in different form. For the EFL teachers, the semi-structured interview was done, but for the superintendent of Bandung Education Office, the elite interview was done.

The document analysis was done by analysing the content from the internationally published textbooks used in both schools. SHS Bumi utilized Aim High 4 and SHS Pertiwi used Choice as the source of learning. The content analysis, which included the materials and the learning objectives, was done from chapter 1 to chapter 4 from each book.

The classroom observation was done to one EFL teachers (Ms. Ruth) from SHS Bumi and two EFL teachers (Ms. Dinda and Ms. Lena) by taking notes on how they conduct the teaching at the classroom to see how they utilize the internationally published textbook and how they did teaching approach, whether it fully follows the textbooks or follow the core and basic competencies in Curriculum 2013.

\section{FINDINGS AND DISCUSSION}

This section intends to address the aims of the study to elaborate the utilization process of the internationally published textbooks within the framework of Curriculum 2013 and the beliefs of the teachers and the managements' staff on the internationally published textbook and Curriculum 2013. The process of utilization is divided into three subsection which are the process of selecting the learning materials, setting the goal of learning, and teaching the materials in the classroom.

In the discussion section, the four sections above are specified into two major topics namely (1) the tension happened in the utilization process of the internationally published textbook within Curriculum 2013 and (2) the tension found in the teachers' and staff managements' beliefs about internationally published textbooks and Curriculum 2013. The findings from both schools are compared to the findings from the superintendant of Bandung Education Office as the parameter of how Curriculum 2013 is ideally practiced in teaching.

\subsection{The Utilization Process of the Internationally Published Textbook within Curriculum 2013}

\subsubsection{The Process of Selecting the Learning Materials}

SHS Bumi and SHS Pertiwi utilized different internationally published textbooks. SHS Bumi chose Aim High 4 written by Paul Kelly and Susan Iannuzzi published by Oxford University Press; meanwhile, SHS Pertiwi chose Choices written by Michael Harris and Anna Sikorzynska published by Pearson Education Limited.

The EFL teachers of SHS Bumi selected the materials from the internationally published textbook (Aim High 4) by doing some adjustments with Curriculum 2013 and also by teaching the materials directly from the internationally published textbook if the materials are not in line with the basic competencies in Curriculum 2013. This approach is named as 'Cambridge approach'. They acknowledge using Curriculum 2013 as the tool to guide them in selecting the materials from the textbook by focusing on description of core competence (KI-3) in the EFL Syllabus.

Meanwhile, the EFL teachers of SHS Pertiwi acknowledge that they did not select the materials from the internationally published textbook (Choices). They did the selection by doing a so-called review process in the beginning of the semester in MGMP (Musyawarah Guru Mata Pelajaran) or English Teacher Working Group before deciding what internationally published textbook they want to choose as the learning source.

\subsubsection{The Process of Setting the Goal of Learning}

In the process of setting the goal of learning, there is a similarity found between SHS Bumi and SHS Pertiwi. The EFL teachers from both schools set their goal of learning on the mastery of the four skills in English. Teaching the four skills becomes their goal of teaching English using the internationally published textbooks.

Both schools admitted that they are using Curriculum 2013 as the guideline in teaching English. However, it is only the EFL teachers from SHS Bumi that attempted to use Curriculum 2013 in the process of setting the goal of learning by following the goal stated in KI-3 of Curriculum 2013, even though in the process of learning the EFL teachers of SHS Bumi concern on teaching the four skills of English.

Meanwhile, the EFL teachers of SHS Pertiwi admitted they did not follow any goal or description in 
Curriculum 2013 as they have set their own goals of learning, which are the mastery of the four skills and the capability in performing well in standardized test of English such as TOEFL, IELTS, and also National Examination.

\subsubsection{The Process of Teaching the Materials}

The process of teaching the materials in SHS Bumi happened by including the four skills. The learning is firstly focused on the mastery of the vocabulary. From vocabulary, the teaching is expanded to reading and writing. To enhance the students' ability in speaking, the EFL teachers of SHS Bumi teach them by using English, but sometimes they switch it into Indonesian language.

The process of teaching English using internationally published textbook is sometimes interrupted by the urgent to face a test named Cambridge Test. It is a kind of test conducted by a private education institution to see if the students have reached the minimum standard of English proficiency. To achieve the goal of the Cambridge Test, the learning activity is brought in the form of grammatical drilling. This fact indicates that the teaching process in SHS Bumi did not fully follow Curriculum 2013

On the other hand, the process of teaching English in SHS Pertiwi happened by focusing more on the grammatical content. As elaborated previously, the EFL teachers of SHS Pertiwi chose to fully follow the guidance given in the internationally published textbook used. The observation data show that the learning was dominated by doing the grammatical exercises and closed by reviewing the material through game named Kahoot!

\subsection{How the Teachers of SHS Bumi and SHS Pertiwi Utilize the Internationally Published Textbook within Curriculum 2013}

The process of selecting the materials from the internationally published textbook done in SHS Bumi by letting the EFL teachers use their professional competence in adjusting the materials provided in the internationally published textbook (Aim High 4) with the description of core competence (KI-3) from Curriculum 2013. However, the EFL teachers from SHS Bumi are also allowed to teach the materials as what is described in the textbook if it is not match with the description of KI-3.

There was tension found in the process of adjusting the materials from the internationally published textbook (Aim High 4) with Curriculum 2013 where the teachers needed to teach two chapters at one meeting. However, it is found as not too burdening as they are also allowed to teach the material as it is if it is not match with the basic competencies demanded from Curriculum 2013.
Compared to SHS Pertiwi, the EFL teachers used their professional competence in choosing the internationally published textbook by discussing and reviewing it in the MGMP (Musyawarah Guru Mata Pelajaran). The reviewing process was done by attempting to teach the materials from the internationally published textbook for one semester and measuring the capability of their students in absorbing the materials. Once the textbook is chosen, they fully follow the guidance and materials provided in the textbook. It means there was no tension happens in the process of selecting the teaching materials as there is no adjustment process done between the internationally published textbook and Curriculum 2013.

Speaking about setting the goal of learning, the EFL teachers from both schools have the same goal which is the mastery of the four skills in English. However, the EFL teachers from SHS Bumi still linked this goal to the description of KI-3 from Curriculum 2013. Meanwhile, the teachers of SHS Pertiwi set additional goal of learning English which is to make the students able to use English communicatively and perform well in standardized test such as TOEFL, IELTS, and UN (National Examination).

In the process of teaching, the EFL teachers of SHS Bumi taught the materials by focusing on the four skills learn in English through the materials from the internationally published textbook. So, there was no tension happening in the process of teaching as the teachers are given right to explore the textbook without being bounded to the demand of Curriculum 2013.

Meanwhile, the EFL teachers from SHS Pertiwi taught the materials by focusing more on the grammatical knowledge. Even though, in the interview, they stated that their goal is to make their students able to communicate in English, but in the process of teaching, they focused on the grammatical content. So, it can be said that there was no tension happen in the process of teaching the materials from the internationally published textbook.

\subsubsection{The Teachers' and Staff Managements' Beliefs on the Internationally Published Textbook and Curriculum 2013}

The EFL teachers from SHS Bumi have a positive belief on the utilization of the internationally published textbook to accommodate the needs of the students. They attempted to adjust by doing a mapping between the basic competencies from Curriculum 2013 and the materials from the internationally published textbook, even though they were not really familiar enough with the terms used in Curriculum 2013.

Two major values from Curriculum 2013 that were used as the guidance by them were HOTS (High Order Thinking Skill) and good character building. 
On the other side, the EFL teachers from SHS Pertiwi indicate that they have a tendency to perceive Curriculum 2013 as a burden to its practice of utilizing the internationally published textbook. They believe that following the basic competencies from Curriculum 2013 create a problematic situation because the materials from the internationally published textbook are different from the basic competencies demanded.

Mrs. Marini, the superintendent of Bandung Education Office said that the reason why many teachers perceive Curriculum 2013 in a negative way because they do not really understand what is demanded from the basic competencies described in the syllabus. She believes that Curriculum 2013 is very flexible to put in practice if the teachers understand the five core components of the lesson plan such as the core competencies, the basic competencies, the indicator of academic achievement, learning materials and learning activities. Understanding and flexibility are what is needed to put Curriculum 2013 in the practice of teaching English using the internationally published textbooks.

Furthermore, Mrs. Marini emphasized that it is not true if the teachers only based their teaching on the achievement of KI-3 (knowledge aspect) because in the real workforce, the attitude and skills are what is needed. In the end, Indonesia (even the world) needs the outcomes (learners) who are fluent in communication in English and also have a good character.

\section{CONCLUSION}

This study has elaborated the utilization process of the internationally published textbook within the framework of Curriculum 2013 and the beliefs that are possessed by the teachers and the managements' staffs from both schools. Both schools acknowledge that Curriculum 2013 is the national standard curriculum, but it is only the teachers from SHS Bumi that attempted to do adjustment between the materials from the internationally published textbook with the basic competencies in Curriculum 2013.

The utilization of the internationally published textbook cannot fully follow the framework of Curriculum 2013 because each was made by different party with different purpose. The tension does not seem to be the major problem because on one side, the EFL teachers of SHS Bumi were still allowed to teach based on the materials from the internationally published textbook with what so-called as the 'Cambridge approach' if the materials in the internationally published textbook did not meet the basic competencies from Curriculum 2013. On the other side, the EFL teachers from SHS Pertiwi were freed to not follow the basic competencies and fully follow the learning objectives provided by the internationally published textbooks.
The implication from this study is that first, the teachers need to make a students' need analysis before deciding what internationally published textbook to be used. Second, it is important for the EFL teachers to do MGMP seriously because it is one of the solutions to minimalize the gap between the materials from the internationally published textbook with the basic competencies demanded from Curriculum 2013. Third, the understanding of the essence of core and basic competencies is important to be possessed by the teachers because they are the indicators that can help the teachers to guide their teaching and set their goal of teaching English to the students. Fourth, because utilizing the internationally published textbook within Curriculum 2013 requires more time to learn despite of the limited time of learning English that the teachers have, they need to be discipline and prepare what to teach in every meeting and be concern about the time usage in their classroom so that the learning can run effectively.

\section{ACKNOWLEDGMENTS}

This study was supported by a grant from two lecturers at English Department at Postgraduate of Indonesia University of Education, Yanty Wirza and Bachrudin Musthafa. The authors would like to express appreciation for all the support provided to finalize the project.

\section{REFERENCES}

Bolton, K. (2012). World Englishes and Asian Englishes: A survey of the field. In A. Kirkpatrick and R. Sussex (Eds.). English as an international language in Asia: Implication for Language Education (pp. 13-26). New York, London: Springer.

Chakravarti, P. (2008). Decolonising and globalising English studies: The case of English textbooks in West-Bengal, India. English in Education, 4(1), 37-52.

Creswell, J. W. (2012). Educational research: Planning, conducting, and evaluating quantitative and qualitative research ( $4^{\text {th }}$ ed.). Boston, MA: Pearson Education, Inc.

Davies, P., \& Pearse, E.(2000). Success in English Teaching. Oxford and New York: OUP.

Eggins, S. (2004). An introduction to systemic functional linguistics ( $2^{\text {nd }}$ ed.). London: Continuum International Publishing Group.

Halliday, M. A. (1978). Language as social semiotics: The social interpretation of language and meaning. London: Edward Arnold.

Kementerian Pendidikan dan Kebudayaan. (2014). Konsep dan implementasi Kurikulum 2013. Jakarta: Kemdikbud. 
Kirkgoz, Y. (2009). Globalization and English language policy in Turkey. Educational Policy, 23(5), 663684.

Ledger,S., Vidovich, L., \& O’Donoghue, T. (2014). International and remote schooling: Global to local curriculum policy dynamics in Indonesia. Asia-Pacific Edu Res, 17, 1-9.

Lindsay, P. (2000). Teaching English Worldwide. Utah: Alta Book Centre.

Murphy, R. S. (2018). The concept of syllabus design and curriculum development: A look at five major syllabus designs. In Faravani, A., Zeraatpishe, M., Azarnoosh, M., Kargozari, H. R. (Eds.), Critical new literacies: Issues in syllabus design (pp. 1-24). Rotterdam, Netherland: Sense Publishers.

Nunan, D. (2003). The impact of English as a global language on educational policies and practices in the Asia-Pacific Region. TESOL Quarterly, 37(4), 589-613.

Peterson, E., \& Coltrane, B. (2003). Culture in second language teaching. Retrieved from http://www.cal.org/resources/digest/0309peterso n.html

Sheedy, J. (2011). Civilization differences-east and west. Retrieved from http://www.drsheedy.com/civilizations-andhistory/civilization-differences-east-andwest.php

Swan, M., \& Smith, B. (2001). Learner English: A teacher's guide to interference and other problems. ( $2^{\text {nd }}$ Ed.). Cambridge: Cambridge University Press.

Taki, S. (2008). International and local curricula: The question of ideology. Language Teaching Research, 12(1), 127-142.

Tomlinson, B. (2012). Materials development for language learning and teaching. Language Teaching, 45(2), 143-178.

Vijaysimha, I. (2013). 'We are textbook badnekais!': A Bernstenian analysis of textbook culture in science classroom. Contemporary Education Dialogue, 10(1), 67-97.

Yin, R. K. (2003). Case study research design and method ( $3^{\text {rd }}$ ed.). Thousand Oaks, CA: SAGE Publication, Inc.

Yulia, Y. (2013). Teaching challenges in Indonesia: Motivating students and teacher's classroom language. Indonesian Journal of Applied Linguistics, 3(1), 1-13.

Zacharias, N. T. (2005). Teachers' beliefs about internationally-published materials: A survey of tertiary English teachers in Indonesia. RELC Journal, 36(1), 23-37. 